\title{
Penerapan Konseling Kelompok Rational Emotive Behavior dan Psikoedukasi di Sekolah Islam; Dampaknya terhadap Penalaran Moral Siswa
}

\author{
Purwati Purwati ${ }^{1}$, Muhammad Japar ${ }^{2}$, Laili Qomariyah ${ }^{3}$ \\ 1,2,3 Universitas Muhammadiyah Magelang \\ 1'bupurwati@ummgl.ac.id, ${ }^{2}$ japar@ummgl.ac.id, ${ }^{3}$ laili.qomariyah@ummgl.ac.id
}

\begin{abstract}
Along with the development of the times and culture's contact from outside, the moral boundaries that are firmly held by the community are increasingly unclear. At school, for example, many students experience a decline in moral reasoning. However, the limited literature that focuses on improving moral reasoning with a quasi-experimental approach, the author will examine psychological interventions Rational Emotive Behavior Counseling (REB) and Psychoeducation (PSE). This study aims to identify differences in effectiveness between group counseling interventions with PSE and REB in improving students' moral reasoning. The author uses a quasi-experiment with a pretest-posttest follow-up design. The study subjects were Sarbini Islamic Junior High School students who had low moral levels. The research subjects consisted of 22 students divided into 11 students in the PSE group and 11 students in the counseling group with the REB approach. The data analysis results showed differences in students' moral reasoning in the REB and PSE groups. The average increase in students' moral reasoning was higher in the REB group than in the PSE group. The author concludes that group counseling with REB and PSE approaches can be applied to improve moral reasoning in students in schools, especially those based on Islam. However, for more optimal results, the authors suggest using REB.
\end{abstract}

Keywords: Counselling, Psychoeducation, REB, Youth Morals

\begin{abstract}
Abstrak
Seiring berkembangnya zaman dan masuknya budaya-budaya dari luar, batasbatas moral yang dipegang teguh oleh masyarakat semakin tidak jelas. Di sekolah, misalnya, banyak siswa mengalami penurunan dalam hal penalaran moral. Namun dengan terbatasnya literatur yang fokus pada meningkatkan penalaran moral dengan pendekatan quasi eksperimen, maka penulis akan mengkaji intervensi psikologis Rational Emotive Behavior Counselling (REB) dan Psikoedukasi (PSE). Penelitian ini bertujuan untuk mengidentifikasi perbedaan efektivitas antara intervensi konseling kelompok dengan PSE dan REB dalam meningkatkan penalaran moral siswa. Penulis menggunakan eksperimen kuasi dengan pretestposttest follow-up design. Subjek dari penelitian adalah siswa Sekolah Menengah Pertama Islam Sarbini yang memiliki tingkat moral yang rendah. Subjek penelitian terdiri dari 22 siswa yang terbagi menjadi 11 siswa pada kelompok PSE dan 11 siswa pada kelompok konseling dengan pendekatan REB. Hasil analisis data menunjukkan bahwa terdapat perbedaan penalaran moral siswa pada
\end{abstract}


kelompok REB dan PSE. Rerata peningkatan penalaran moral siswa terlihat lebih tinggi pada kelompok REB dibandingkan dengan PSE. Penulis menyimpulkan bahwa penggunaan konseling kelompok dengan pendekatan REB dan PSE dapat diterapkan untuk meningkatkan penalaran moral pada siswa di sekolah-sekolah terutama yang berbasis Islam. Namun, untuk hasil yang lebih optimal penulis menyarankan untuk menggunakan REB.

Kata Kunci: Konseling, Moral Remaja, Psikoedukasi, REB

\section{Pendahuluan}

Remaja merupakan tahapan di mana individu berada pada masa transisi dari anakanak menuju dewasa. ${ }^{1}$ Beberapa peneliti mengatakan bahwa remaja merupakan masa yang tepat untuk mengembangkan sensitivitas moral agar dapat memiliki kemampuan berpikir abstrak yang lebih baik, mampu memilih pespektif, dan memiliki pengetahuan yang lebih mengenai masalah-masalah sosial. ${ }^{2}$ Perilaku remaja dapat dilihat dari berbagai macam perspektif waktu. ${ }^{3}$ Untuk memahami ini, remaja yang melakukan perilaku berisiko dapat diakibatkan oleh adanya kegagalan perkembangan pada tahap sebelumnya. ${ }^{4}$

Penalaran moral merupakan proses kognitif yang terjadi pada seseorang ketika mengalami dilema, terutama yang berkaitan dengan etika. ${ }^{5}$ Penalaran moral merupakan faktor penentu utama bagi seseorang dalam perilaku moral dan etika. ${ }^{6}$ Penalaran moral remaja telah banyak dibahas dan diteliti di dunia akademik. Akan tetapi di setiap penelitian selalu ada kebaruan di dalamnya. Hal ini dikarenakan penalaran moral remaja terbentuk dan dipengaruhi oleh dari banyak faktor. Faktor yang memengaruhi moral remaja adalah

\footnotetext{
${ }^{1}$ Jeffrey Jensen Arnett, "Emerging Adulthood: A Theory of Development from the Late Teens through the Twenties," American Psychologist 55, no. 5 (2000): 469-80, https://doi.org/10.1037/0003-066X.55.5.469.

${ }^{2}$ Melanie Killen dan Judith G. Smetana, ed., "Empathy-Related Responding in Children," dalam Handbook of Moral Development, 2 ed. (Psychology Press, 2013); Tobias Krettenauer, "Pro-Environmental Behavior and Adolescent Moral Development," Journal of Research on Adolescence 27, no. 3 (2017): 581-93, https://doi.org/10.1111/jora.12300; Zena R Mello dan Frank C Worrel, "The Past, the Present, and the Future: A Conceptual Model of Time Perspective in Adolescence," Time Perspective Theory; Review, Research and Application: Essays in Honor of Philip G. Zimbardo, 2015, 1-551, https://doi.org/10.1007/978-3-319-073682.

${ }^{3}$ Philip G. Zimbardo, Kelli A. Keough, dan John N. Boyd, "Present Time Perspective as a Predictor of Risky Driving," Personality and Individual Differences 23, no. 6 (1997): 1007-23, https://doi.org/10.1016/S01918869(97)00113-X.

${ }^{4}$ Mello dan Worrel, "The Past, the Present, and the Future: A Conceptual Model of Time Perspective in Adolescence."

${ }^{5}$ Linda K. Trevino dan Stuart A. Youngblood, "Bad Apples in Bad Barrels: A Causal Analysis of Ethical Decision-Making Behavior.," Journal of Applied Psychology 75, no. 4 (1990): 378-85, https://doi.org/10.1037/0021-9010.75.4.378.

${ }^{6}$ Subodh Kulkarni dan Nagarajan Ramamoorthy, "Intra-Firm Transfer of Best Practices in Moral Reasoning: A Conceptual Framework," Business Ethics: A European Review 23, no. 1 (Januari 2014): 15-33, https://doi.org/10.1111/beer.12035; Ashish Pandey, Rajesh Chandwani, dan Ajinkya Navare, "How Can Mindfulness Enhance Moral Reasoning? An Examination Using Business School Students," Business Ethics: A European Review 27, no. 1 (Januari 2018): 56-71, https://doi.org/10.1111/beer.12171.
} 
lingkungan sekolah, teman sebaya, dan pendidikan keluarga. ${ }^{7}$ Faktor-faktor tersebut sifatnya adalah dinamis sehingga akan membuat moral remaja juga terus mengalami perubahan dan perkembangan. Lebih jauh, faktor-faktor yang dapat memprediksi penalaran moral adalah agama, karakter demografis, status sosial, spiritualitas, dan identitas moral. ${ }^{8}$

Beberapa penelitian telah menunjukkan bahwa penalaran moral dapat ditingkatkan. ${ }^{9}$ Psikoedukasi merupakan salah satu intervensi yang dapat digunakan untuk menurunkan moral pada remaja. Psikoedukasi dimaknai sebagai modalitas perbaikan atau peningkatan yang disampaikan secara profesional dengan cara mengintegrasikan dan menyinergikan intervensi psikoterapi dan pendidikan. ${ }^{10}$ Carmen menyatakan bahwa psikoedukasi terdiri dari pemberian informasi dan pendidikan, konseling, relaksasi dan teknik pencitraan, serta terapi perilaku kognitif. ${ }^{11}$ Psikoedukasi dilakukan berdasarkan kekuatan dan fokus pada kondisi saat ini. ${ }^{12}$ Proses psikoedukasi bertujuan untuk menghilangkan hambatan secara komprehensif yang terjadi pada individu dengan cara membantu individu dalam mencerna dan menemukan strategi dalam memahami informasi dan pengetahuan yang bermanfaat bagi peningkatan kualitas hidupnya. ${ }^{13}$ Selain itu, psikoedukasi mampu memberikan dampak pada peningkatan moral melalui penekanan kognisi tanggung jawab. Hal ini dikarenakan perilaku

\footnotetext{
7 Jacquelynne S. Eccles dan Robert W. Roeser, "Schools as Developmental Contexts," Blackwell Handbook of Adolescence, 2008, 129-48, https://doi.org/10.1002/9780470756607.ch7; Simona C.S. Caravita dkk., "Peer Influences on Moral Disengagement in Late Childhood and Early Adolescence.," Journal of Youth and Adolescence 43, no. 2 (2014): 193-207, https://doi.org/10.1007/s10964-013-9953-1.

${ }^{8}$ Almerinda Forte, “Antecedents of Managers Moral Reasoning," Journal of Business Ethics 51, no. 4 (Juni 2004): 313-47, https://doi.org/10.1023/B:BUSI.0000032501.59580.33; Scott J. Vitell dkk., "Spirituality, Moral Identity, and Consumer Ethics: A Multi-Cultural Study," Journal of Business Ethics 139, no. 1 (November 2016): 147-60, https://doi.org/10.1007/s10551-015-2626-0.

${ }^{9}$ Matthew J. Mayhew dan Patricia King, "How Curricular Content and Pedagogical Strategies Affect Moral Reasoning Development in College Students," Journal of Moral Education 37, no. 1 (1 Maret 2008): 17-40, https://doi.org/10.1080/03057240701803668; Katerina Mouratidou, Stavroula Goutza, dan Dimitrios Chatzopoulos, "Physical Education and Moral Development: An Intervention Programme to Promote Moral Reasoning through Physical Education in High School Students," European Physical Education Review 13, no. 1 (1 Februari 2007): 41-56, https://doi.org/10.1177/1356336X07072675; Pandey, Chandwani, dan Navare, "How Can Mindfulness Enhance Moral Reasoning?"; Christopher D. Schmidt, Charles R. McAdams, dan Victoria Foster, "Promoting the Moral Reasoning of Undergraduate Business Students through a Deliberate Psychological Education-based Classroom Intervention," Journal of Moral Education 38, no. 3 (1 September 2009): 315-34, https://doi.org/10.1080/03057240903101556.

${ }^{10}$ Ellen P. Lukens dan William R. McFarlane, "Psychoeducation as Evidence-Based Practice: Considerations for Practice, Research, and Policy," Brief Treatment and Crisis Intervention 4, no. 3 (2004): 205-25, https://doi.org/10.1093/brief-treatment/mhh019.

${ }^{11}$ Carmen W.H. Chan, "Psychoeducational Intervention: A Critical Review of Systematic Analyses," Clinical Effectiveness in Nursing 9, no. 3-4 (2005): 101-11, https://doi.org/10.1016/j.cein.2006.08.011.

${ }_{12}$ Lukens dan McFarlane, "Psychoeducation as Evidence-Based Practice: Considerations for Practice, Research, and Policy."

${ }^{13}$ David Mechanic, "Improving the Quality of Health Care in the United States of America: The Need for a Multi-level Approach," Journal of Health Services Research and Policy 7, no. SUPPL. 1 (2002): 35-39, https://doi.org/10.1258/135581902320176359.
} 
yang amoral disebabkan karena adanya bias kognitif. ${ }^{14}$ Hasil penelitian dari Worthington dan Langberg ${ }^{15}$ menunjukkan bahwa dengan pertimbangan agama dan pemaafan diri melalui psikoedukasi mampu menurunkan trauma kompleks dan cedera moral pada tentara.

Luasnya ranah moral bagi remaja membuat para peneliti melakukan berbagai macam metodologi dalam menginvestigasi moral remaja. ${ }^{16}$ Hal ini dikarenakan luasnya cakupan dari perilaku yang mencerminkan sebuah nilai moral di setiap aspek dan indikatornya yang tentu saja penanganannya membutuhkan kesesuaian di masing-masing permasalahan yang terjadi. Salah satu intervensi yang bisa dilakukan dalam meningkatkan moral khususnya remaja adalah dengan cara rational emotive behavior therapy (REB). REB dikembangkan oleh Ellis pada tahun 1955 yang merupakan sebuah terapi yang menyasar pada sebuah kepercayaan individu. ${ }^{17}$ Secara umum REB akan membantu klien untuk beberapa hal, di antaranya: 1) menyadari kesalahannya yang tentu saja lingkungan juga berperan dalam hal tersebut, 2) memberi keyakinan dan menyadarkan individu bahwa mereka mampu mengatasi permasalahannya sendiri, 3) memahamkan mereka bahwa masalah mereka sebagian besar berasal dari keyakinan irasional, 4) mendeteksi keyakinan irasional mereka dan bedakan antara mereka dan keyakinan rasional mereka, 5) serta mendorong mereka untuk menemukan perbedaan yang nyata antara keyakinan irasional dan rasional sehingga mereka mampu mengonstruksi keyakinan mereka menjadi keyakinan yang rasional dan konstruktif. ${ }^{18}$ Hal ini sangat berkaitan dengan moral individu karena moral merupakan sebuah keyakinan dan nilai individu terkait dengan apa yang mereka yakini benar dan kemudian diwujudkan dalam sebuah perilaku. REB mampu mengarahkan para remaja agar dapat berpikir secara rasional dalam pembentukan karakter remaja. ${ }^{19}$ Bentuk lain dari intervensi dalam meningkatkan moral remaja adalah melalui psikoedukasi. REB dan Psikoedukasi juga sudah diterapkan pada populasi Muslim. ${ }^{20}$

14 Teresa Marino Carper dkk., "The Effects of Psychoeducation on Thought-action Fusion, Thought Suppression, and Responsibility," Journal of Behavior Therapy and Experimental Psychiatry 41, no. 3 (2010): 289-96, https://doi.org/10.1016/j.jbtep.2010.02.007.

${ }^{15}$ Everett L. Worthington dan Diane Langberg, "Religious Considerations and Self-forgiveness in Treating Complex Trauma and Moral Injury in Present and Former Soldiers," Journal of Psychology and Theology 40, no. 4 (2012): 274-88, https://doi.org/10.1177/009164711204000403.

${ }^{16}$ Daniel Hart dan Gustavo Carlo, "Moral Development in Adolescence The Intersection of Morality and Adolescence" 15, no. 3 (2005): 223-33.

${ }^{17}$ Daniel David, "Rational Emotive Behavior Therapy (REBT)," The Encyclopedia of Clinical Psychology, 2015, 1-8, https://doi.org/10.1002/9781118625392.wbecp077.

${ }^{18}$ David.

${ }^{19}$ Hastiani dan Rustam, "Fenomena Karakter Remaja SMA Kota Pontianak dan Kajian pada Rational Emotive Behavior Therapy (Rebt) Multikultural Hastiani 1, Rustam 2" 1, no. 1 (2019): 8-20.

${ }^{20}$ Muhammad Ahmud dan Mohamad Thohir, "Konseling Islam dengan Terapi Rasional Emotif Behavior untuk Mengubah Wanita Penyanyi Cafe yang Suka Minum Minuman Keras," Jurnal Bimbingan dan Konseling Islam 3, no. 2 (2013): 184-204; Hariyati Mustika Dewi, "Konseling Islam dengan Terapi Rasional Emotif Behavior 
Berdasarkan beberapa penelitian yang telah dilakukan oleh para peneliti sebelumnya terkait dengan intervensi yang dilakukan dalam meningkatan penalaran moral dan tidak fokus pada populasi Muslim, maka peneliti bermaksud untuk menguji efektivitas dari kedua intervensi yang telah dijelaskan sebelumnya pada populasi Muslim. Penelitian ini bertujuan untuk melihat tingkat efektivitas konseling dengan pendekatan psikoedukasi maupun dengan rational emotif behavior. Berdasarkan literatur dan penjelasan tersebut maka peneliti memiliki asumsi awal bahwa rational emotif behavior therapy lebih efektif dalam upaya meningkatkan moral pada usia remaja.

\section{Metode}

\section{Desain Penelitian}

Penulis menggunakan pendekatan kuasi eksperimen grup pretest-posttest, dan follow-up.

\section{Partisipan}

Penelitian ini dilakukan di Sekolah Menengah Pertama Islam Sarbini Grabag Kabupaten Magelang. Pada tahap penentuan partisipan, 40 orang siswa diundang untuk mengisi skala moralitas, 22 orang siswa dengan skor terendah diundang untuk mengikuti tahap eksperimen. Kemudian, partisipan dibagi menjadi dua kelompok yaitu kelompok eksperimen rasional emotif behavior $(\mathrm{n}=11)$ dan kelompok psikoedukasi $(\mathrm{n}=11)$. Partisipan terdiri dari 8 laki-laki dan 14 perempuan dengan rentang usia 13 sampai dengan 17 tahun $(\mathrm{M}=14 ; \mathrm{SD}=.66)$.

\section{Intervensi}

\section{Rasional Emotif Behavior}

Dalam penelitian ini, penulis mendesain REB untuk meningkatkan moralitas remaja. REB menekankan bahwa tingkah laku yang bermasalah disebabkan oleh pemikiran yang

\footnotetext{
dalam Mengatasi Stres Ibu Muda di Desa Boteng Menganti Gresik" (PhD Thesis, UIN Sunan Ampel Surabaya, 2019); Hany Paturrochmah, "Rasional Emotif Behavior Therapy (REBT) Islam dalam Menumbuhkan Sikap Mental Positif," Konseling Edukasi: Journal of Guidance and Counseling 4, no. 2 (2020): 200-217; Yuwinda Ardila, Anwar Sutoyo, dan Mulawarman Mulawarman, "Keefektifan Kelompok Psikoedukasi dengan Teknik Modeling untuk Meningkatkan Keterampilan Sosial Siswa," Jurnal Edukasi: Jurnal Bimbingan Konseling 5, no. 1 (2020): 34-49; Imam Setyo Nugroho, "Keefektifan Kelompok Psikoedukasi Teknik Modeling Berbasis Nilai-Nilai Islam untuk Menurunkan Moral Disengagement dan Meningkatkan Integritas Akademik Siswa" (PhD Thesis, Universitas Negeri Semarang, 2019); Warzuknidini Warzuknidini, Amelia Pramono, dan Marindra Firmansyah, "Pengaruh Psikoedukasi Pencegahan Penyalahgunaan Narkoba terhadap Perubahan Sikap Mahasiswa Fakultas Kedokteran Universitas Islam Malang," Jurnal Bio Komplementer Medicine 7, no. 1 (2020).
} 
irasional, di mana penyebab utama masalah ini adalah keyakinan mereka bahwa akan banyak memiliki kegagalan dalam menguasai pelajaran-pelajaran tertentu yang dianggap sulit.

Dalam panduan ini menjelaskan tahap demi tahap yang dilakukan untuk menguji pengaruh konseling kelompok dengan pendekatan REB terhadap pengembangan moral remaja yang meliputi: tahap pembentukan, orientasi dan eksplorasi, transisi, pelaksana kerja, konsolidasi dan terminasi, serta evaluasi dan tindak lanjut. Konseling kelompok dilaksanakan maksimal 8 kali pertemuan dengan durasi 60-120 menit dalam setiap pertemuan. Partisipan kelompok rasional emotif behavior terdiri dari 11 orang siswa (Lakilaki $=6$; Perempuan $\left.=5 ; \mathrm{M}_{\mathrm{age}}=14\right)$. Tahapan pelaksanaan dapat dilihat pada tabel 1 .

\section{Psikoedukasi}

Psikoedukasi bertujuan untuk mendorong pertumbuhan pribadi sesuai dengan tahap perkembangan, memberikan informasi yang relevan, dan menyelesaikan masalah atau konflik. Menurut Stuart \& Laraia, psikoedukasi merupakan salah satu elemen program perawatan kesehatan mental dengan cara pemberian informasi dan edukasi melalui komunikasi terapeutik. Tahapan yang dilakukan untuk menguji pengaruh Psikoedukasi kelompok terhadap pengembangan moral remaja yang meliputi tahap pembentukan, orientasi dan eksplorasi, transisi, pelaksana kerja, konsolidasi dan terminasi, serta evaluasi dan tindak lanjut. Konseling kelompok dilaksanakan sebanyak 8 kali dengan durasi 60-120 menit dalam setiap pertemuan. Partisipan kelompok psikoedukasi terdiri dari 11 orang siswa $\left(\right.$ Laki-laki $=2 ;$ Perempuan $\left.=9 ; \mathrm{M}_{\mathrm{age}}=14.18 ; \mathrm{SD}_{\mathrm{age}}=.93\right)$.

\section{Group Leader}

Pemimpin kelompok REB dan Psikoedukasi merupakan orang yang berpengalaman dengan latar belakang pendidikan Bimbingan dan Konseling. Sebelum melakukan intervensi penelitian, pemimpin kelompok mendapatkan pelatihan dari praktisi profesional di bidang bimbingan konseling yang telah mendapat rekognisi sebagai guru besar. Pelatihan dan pembekalan dilaksanakan selama satu minggu. Selain mendapatkan pelatihan, proses intervensi juga mendapatkan pengawasan langsung oleh ahli tersebut. Setelah dievaluasi dan dinyatakan layak untuk melaksanakan intervensi, pemimpin kelompok tersebut diberikan izin menemui partisipan dan melaksanakan konseling REB dan Psikoedukasi. Briefing dan evaluasi dilakukan oleh pengawas sebelum dan sesudah setiap sesi intervensi. 


\section{Instrumen}

Penulis menggunakan skala moral remaja yang dikembangkan sendiri oleh penulis untuk penelitian ini. Skala moral remaja tersebut memiliki 50 item pernyataan, berikut adalah beberapa contoh pernyataannya "Saya terbiasa mengatakan apa adanya kepada siapapun", "Saya meminta maaf kepada orang lain saat melakukan kesalahan", "Saya sering lupa menepati janji dengan teman saya saat saya sibuk", dan "Saya pernah menertawakan teman saya yang terjatuh”. Setelah dilakukan uji validitas, nilai loading skala moral siswa berkisar dari $r=.372$ sampai dengan $r=.630$. Sementara, hasil pengujian reliabilitas menjukkan tingkat yang memuaskan $(\alpha=.939)$.

\section{Prosedur}

Penelitian ini dilaksanakan setelah mendapatkan persetujuan dari Lembaga Penelitian dan Pengabdian Universitas Muhammadiyah Magelang. Partisipan yang dilibatkan dalam penelitian ini adalah siswa dengan skor moralitas di bawah rerata. Mereka diberikan penjelasan mengenai latar belakang, tujuan, dan metode penelitian. Kemudian mereka diminta untuk mengisi kesediaan mengikuti semua tahapan penelitian. Skor moralitas pada tahap seleksi partisipan dijadikan sebagai data pretest. Setelah delapan kali pertemuan, baik dengan rasional emotif behavior atau psikoedukasi, partisipan diminta untuk mengisi kembali skala moral remaja yang kemudian dijadikan sebagai data posttest. Data follow-up diambil setelah satu bulan sejak pertemuan terakhir.

\section{Analisis Data}

Data yang terkumpul dianalisis menggunakan statistic deskriptif dan three way mixed ANOVA. 


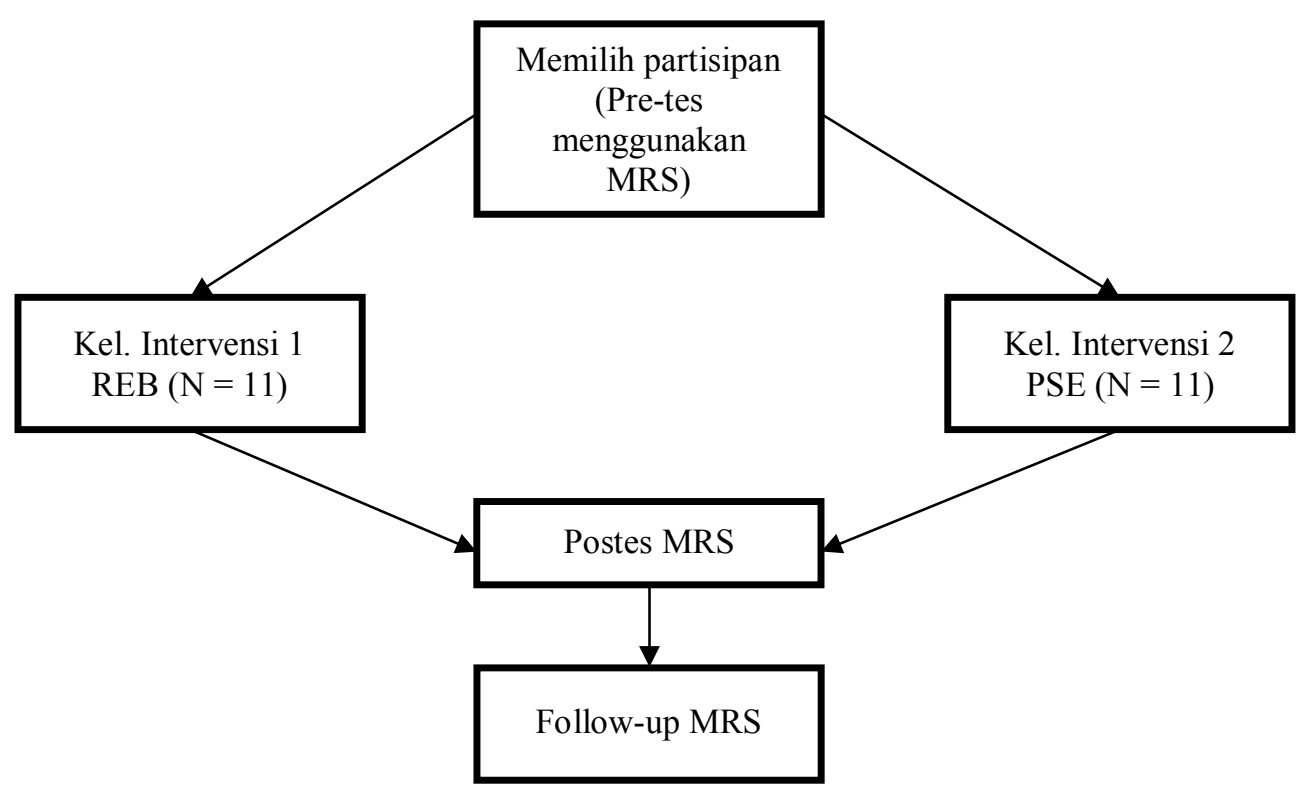

Gambar 1. Kerangka Berpikir Penelitian

\section{Pembahasan}

\section{Hasil}

Penulis melakukan uji Normalitas data untuk REB Pretest $\left(\mathrm{T}_{1}\right)$, REB Posttest $\left(\mathrm{T}_{2}\right)$, REB Follow-up ( $\left.T_{3}\right)$, PSE Pretest $\left(T_{1}\right)$, PSE Posttest $\left(T_{2}\right)$, dan PSE Follow-up ( $T_{3}$ ). Hasil pengujian dengan menggunakan Shapiro-Wilk menunjukkan bahwa semua data tersebut berdistribusi dengan normal dan homogen sehingga dapat dilakukan pengujian lanjutan (lihat Tabel 1).

\begin{tabular}{lllllll}
\hline Group & Time & $M$ & $S D$ & $W$ & $d f$ & $p$ \\
\hline REB & $\mathrm{T}_{1}$ & 139.64 & 2.24 & .91 & 11 & .28 \\
& $\mathrm{~T}_{2}$ & 167.64 & 3.32 & .90 & 11 & .20 \\
& $\mathrm{~T}_{3}$ & 173.09 & 2.42 & .86 & 11 & .05 \\
PSE & $\mathrm{T}_{1}$ & 138.09 & 2.46 & .98 & 11 & .97 \\
& $\mathrm{~T}_{2}$ & 153.09 & 3.96 & .96 & 11 & .79 \\
& $\mathrm{~T}_{3}$ & 160.27 & 4.90 & .87 & 11 & .10 \\
\hline
\end{tabular}

Tabel 1. Analisis Deskriptif pada Tiga Waktu, Uji Normalitas, dan Homogenitas.

\begin{tabular}{lcccccccccc}
\hline Time & \multicolumn{4}{c}{ REB } & \multicolumn{4}{c}{ PSE } \\
\cline { 2 - 10 } Assesment & $M D$ & $S E$ & $p$ & Lower & Upper & $M D$ & $S E$ & $p$ & Lower & Upper \\
\hline T1 - T2 & -28.00 & .66 & $<.01$ & -29.89 & -26.10 & -15.00 & .81 & $<.01$ & -17.32 & -12.67 \\
T1 - T3 & -33.45 & .63 & $<.01$ & -35.28 & -31.62 & -22.18 & 1.09 & $<.01$ & -25.32 & -19.04 \\
T2 - T3 & -5.45 & .66 & $<.01$ & -7.36 & -3.54 & -7.18 & .92 & $<.01$ & -9.83 & -4.53 \\
\hline
\end{tabular}

Tabel 2. Perbandingan Kelompok REB dan PSE dari Time 1 sampai Time 3

Tabel 2 menunjukkan bagaimana perbandingan rerata, standar eror, probabilitas, nilai minimum dan nilai maksimum pada kelompok REB dan PSE dari T1 sampai dengan T2. Secara umum, baik REB ataupun PSE sama-sama memiliki tren yang meningkat. Namun, 
kelompok REB menunjukkan peningkatan yang lebih tinggi dibandingkan dengan kelompok PSE. Pada T1 - T2 kelompok eksperimen, terjadi peningkatan skor penalaran moral dengan selisih $\mathrm{MD}=-28.00$. Pada T1 $-\mathrm{T}$, terjadi peningkat skor penalaran moral dengan selisih $\mathrm{MD}=-33.45$, yang mana skor ini adalah skor selisih yang paling tinggi di antara skor lainnya. Sementara, T2 - T3 terjadi peningkatan dengan selisih $\mathrm{MD}=-5.45$. Sedangkan pada T1 - T2 kelompok kontrol terjadi peningkatan skor penalaran moral dengan selisih MD = 15.00. Pada T1 - T3 terjadi peningkatan dengan selisih $\mathrm{MD}=-25.32$. Sementara pada $\mathrm{T} 2-$ $\mathrm{T} 3$ terjadi peningkatan skor penalaran moral dengan selisih $\mathrm{MD}=\mathbf{- 9 . 8 3}$.

\begin{tabular}{lcccc}
\hline Effect & $F$ & $d f$ & $p$ & $\eta^{2} p$ \\
\hline REB & 1.503 & 2 & $<.01$ & .98 \\
PSE & 284.41 & 2 & $<.01$ & .55 \\
\hline
\end{tabular}

\section{Table 3. Analysis of Three Way Mixed ANOVA}

Hasil pengujian data pre, post, dan follow-up test menunjukkan bahwa efek intervensi REB dari waktu ke waktu (T1 - T3) adalah signifikan $\left(\mathrm{F}(2)=1.503, p<.01, \eta_{\mathrm{p}}^{2}=.98\right)$. Hal ini didukung dengan terjadinya peningkatan skor penalaran moral siswa (Lihat tabel 1 dan figure 2) dari T1 $(M=139.64, S D=2.24)$, T2 $(M=167.64, S D=3.32)$, dan T3 $(M=$ 173.09, $S D=2.42$ ). Pada kelompok PSE, efek intervensi juga menunjukkan hasil yang signifikan $\left(F(2)=284.41, p<.01, \eta^{2}=.55\right)$. Hasil ini didukung skor rerata penalaran (Lihat tabel 1 dan gambar 2) moral yang meningkat dari $\mathrm{T} 1(\mathrm{M}=138.09, \mathrm{SD}=2.46), \mathrm{T} 2(\mathrm{M}=$ 153.09, $\mathrm{SD}=3.96)$, dan T3 $(\mathrm{M}=160.27, \mathrm{SD}=4.90)$.

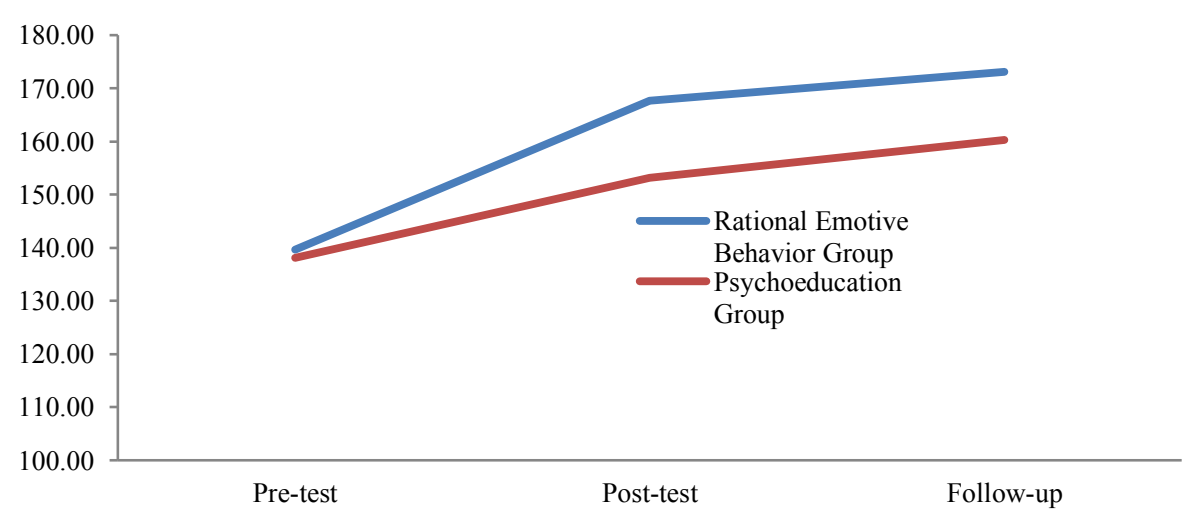

Gambar 2. Peningkatan Penalaran Moral Siswa pada Kelompok REB dan PSE

\section{Pembahasan}

Hasil penelitian menunjukkan bahwa pendekatan konseling REB dan PSE dapat membantu meningkatkan penalaran moral remaja. Hasil penelitian tersebut sesuai dengan tujuan penerapan REB dalam menangani masalah konseli. Penelitian ini sejalan dengan 
temuan penelitian terdahulu yang menunjukkan bahwa REB dan Psikoedukasi merupakan pendekatan yang efektif diterapkan pada populasi Muslim. ${ }^{21}$ REB bukan hanya untuk memberikan pengalaman katarsis tetapi untuk membantu konseli mengubah beberapa pemikiran, emosi, dan perilaku mereka. ${ }^{22}$ REB membahas sikap, emosi yang tidak sehat (misalnya kemarahan yang tidak sehat, depresi, kecemasan, rasa bersalah, dan lain-lain.) Hasil penelitian sejalan dengan hasil-hasil penelitian terdahulu tentang penerapan pendekatan konseling REB dalam menangani berbagai masalah. Penelitian Flanagan, ${ }^{23}$ menunjukkan bahwa REB efektif untuk mengatasi masalah kemarahan. REB efektif mengatasi gangguan emosi pada remaja dalam berbagai pengaturan pendidikan. ${ }^{24}$ Neimeyer ${ }^{25}$ melakukan penelitian mengenai kesedihan dan kesedihan spiritual yang rumit, sebuah krisis kehilangan iman yang salah satu fokus utama dari model rekonstruksi makna berkabung menyangkut makna spiritual yang dikaitkan dengan kematian. REB dapat diterapkan pada segala usia, termasuk pada remaja. Penelitian REB diterapkan pada orang tua sebagaimana dilakukan Terjesen \& Kurasaki $^{26}$ REB merupakan strategi untuk mempromosikan fungsi emosional orang tua dan guru yang lebih efektif, meningkatkan perilaku dan pembelajaran positif anak. REB dapat diterapkan pada anak-anak sebagaimana

\footnotetext{
${ }^{21}$ Muhammad Ahmud dan Mohamad Thohir, "Konseling Islam dengan Terapi Rasional Emotif Behavior untuk Mengubah Wanita Penyanyi Cafe yang Suka Minum Minuman Keras," Jurnal Bimbingan dan Konseling Islam 3, no. 2 (2013): 184-204; Hariyati Mustika Dewi, "Konseling Islam dengan Terapi Rasional Emotif Behavior dalam Mengatasi Stres Ibu Muda di Desa Boteng Menganti Gresik" (PhD Thesis, Uin Sunan Ampel Surabaya, 2019); Hany Paturrochmah, "Rasional Emotif Behavior Therapy (REBT) Islam dalam Menumbuhkan Sikap Mental Positif," Konseling Edukasi: Journal of Guidance and Counseling 4, no. 2 (2020): 200-217; Yuwinda Ardila, Anwar Sutoyo, dan Mulawarman Mulawarman, "Keefektifan Kelompok Psikoedukasi dengan Teknik Modeling untuk Meningkatkan Keterampilan Sosial Siswa," Jurnal Edukasi: Jurnal Bimbingan Konseling 5, no. 1 (2020): 34-49; Imam Setyo Nugroho, "Keefektifan Kelompok Psikoedukasi Teknik Modeling Berbasis Nilai-Nilai Islam untuk Menurunkan Moral Disengagement dan Meningkatkan Integritas Akademik Siswa" (PhD Thesis, Universitas Negeri Semarang, 2019); Warzuknidini Warzuknidini, Amelia Pramono, dan Marindra Firmansyah, "Pengaruh Psikoedukasi Pencegahan Penyalahgunaan Narkoba terhadap Perubahan Sikap Mahasiswa Fakultas Kedokteran Universitas Islam Malang," Jurnal Bio Komplementer Medicine 7, no. 1 (2020).

${ }^{22}$ Windy Dryden, Rational Emotive Behaviour Therapy: Distinctive Features (Routledge, 2021); Albert Ellis dkk., Stress Counselling: A Rational Emotive Behaviour Approach (Sage, 2001).

23 "The Impact of Anger Management Treatment and Rational Emotive Behavior Therapy in a Public School Setting on Social Skills, Anger Management, and Depression," Journal of Rational-Emotive \& CognitiveBehavior Therapy 28, no. 2 (2010): 87-99.

${ }^{24}$ Tachelle Banks dan Paul Zionts, "Teaching a Cognitive Behavioral Strategy to Manage Emotions Rational Emotive Behavior Therapy in an Educational Setting," Intervention in School and Clinic 44, no. 5 (2009): 30713; Tachelle Banks dan Paul Zionts, "REBT Used with Children and Adolescents who Have Emotional and Behavioral Disorders in Educational Settings: A review of the Literature," Journal of Rational-Emotive \& Cognitive-Behavior Therapy 27, no. 1 (2009): 51-65.

25 "Grief Therapy as Intervening in Meaning: Principles and Practices," dalam Alleviating World Suffering (Springer, 2017), 165-79.

26 "Rational Emotive Behavior Therapy: Applications for Working with Parents and Teachers," Estudos de Psicologia (Campinas) 26 (2009): 3-14.
} 
penelitian Caruso, dkk. ${ }^{27}$ bahwa pelatihan berbasis REB untuk anak-anak dan guru harus diintegrasikan ke dalam kurikulum kelas mencegah masalah kesehatan mental dan mendorong kesejahteraan sosial dan emosional yang positif. REB efektif diterapkan pada remaja karena mampu mengarahkan para remaja agar dapat berpikir secara rasional dalam pembentukan karakter remaja. ${ }^{28}$

REB dalam konseling adalah bentuk layanan jangka pendek yang membantu seseorang untuk mengidentifikasi pikiran dan perasaan yang melemahkan, menantang rasionalitas perasaan itu, dan menggantinya dengan keyakinan yang lebih sehat dan lebih produktif. REB kebanyakan berfokus pada saat ini untuk membantu Anda memahami bagaimana pikiran dan keyakinan yang tidak sehat menciptakan tekanan emosional yang, pada gilirannya, mengarah pada tindakan dan perilaku tidak sehat yang mengganggu tujuan hidup Anda saat ini. Setelah diidentifikasi dan dipahami, pikiran dan tindakan negatif dapat diubah dan diganti dengan perilaku yang lebih positif dan produktif, memungkinkan Anda untuk mengembangkan hubungan pribadi dan profesional yang lebih sukses.

Hasil penelitian menunjukkan bahwa konseling psikoedukasi dapat meningkatkan moralitas remaja, karena kelompok psikoedukasi merupakan bentuk intervensi terapeutik yang menggabungkan psikoterapi dan pendidikan. Ini dapat digunakan pada individu, kelompok, keluarga, dan dapat diimplementasikan sendiri atau menerapkan teknik intervensi lainnya. Kelompok psikoedukasi disebut juga sebagai kelompok pendidikan atau bimbingan, yang menekankan pada penggunaan metode pendidikan untuk menyampaikan informasi dan mengembangkan keterampilan. ${ }^{29}$ Tujuan kelompok psikoedukasi memiliki bagian penting yaitu sebagai proses kegiatan pembelajaran dan penyampaian informasi baru. ${ }^{30}$ Tujuan khusus psikoedukasi membantu dalam menyediakan keterampilan dan bimbingan selama masa transisi, mengurangi kecemasan, kemarahan, tekanan emosional lainya, memperbaiki kemampuan interpersonal seperti; memperkuat keterampilan belajar. Kelompok psikoedukasi menjadi bagian integral dari pemberian layanan di bidang konseling, mengembangkan keterampilan untuk merancang pengalaman konseling yang tepat sangat

\footnotetext{
27 "Effects of a REBT Based Training on Children and Teachers in Primary School," Journal of RationalEmotive \& Cognitive-Behavior Therapy 36, no. 1 (2018): 1-14.

${ }^{28}$ Hastiani dan Rustam, "Fenomena Karakter Remaja SMA Kota Pontianak dan Kajian pada Rational Emotive Behavior Therapy (Rebt) Multikultural Hastiani 1, Rustam 2."

${ }^{29}$ Rossi Galih Kesuma, Aji Taufiq Pambudi, dan Septa Nikmatil Aliyah, "Kelompok Psikoedukasi sebagai Strategi Meningkatkan Self-Efficacy Pengambilan Keputusan Karier dan Adaptabilitas Karier Peserta Didik SMP di Kota Semarang," dalam Prosiding Seminar Nasional: Strategi Pelayanan Bimbingan dan Konseling di Era Disrupsi, 2018, 242-47.

${ }^{30}$ Siti Aminah dkk., "Analisis Dampak Pelatihan Peningkatan Kompetensi Layanan Konseling Kelompok pada Guru BK SMA Se-Kabupaten Sleman,” Diklus: Jurnal Pendidikan Luar Sekolah 5, no. 2 (2021).
} 
penting bagi praktisi saat ini khususnya di sekolah. Kelompok psikoedukasi mencakup berbagai topik mencakup topik afektif, dan eksistensial, serta perilaku kognitif. ${ }^{31}$ Penelitian penggunaan psikoedukasi telah dilakukan oleh Pambudi, ${ }^{32}$ hasilnya menunjukkan bahwa kelompok psikoedukasi dengan teknik modeling memberikan pengaruh langsung terhadap adaptasi karir.

Konseling REB memiliki sumbangan yang lebih besar untuk meningkatkan moralitas karena REB memiliki kekuatan pada kesadaran berpikir ilmiah sebagaimana dikemukakan Ellis. Menurut Elis, kekuatan utama dari REB adalah kesadaran berpikir ilmiah. Berpikir ilmiah yang dimaksud adalah cara berpikir rasional. Karena jika seseorang berpikir ilmiah, seseorang dapat menerima - meskipun mungkin tidak menyukainya berbagaimasalah yang tidak dapat diubah dan berhenti mengubah masalah-masalah tersebutmenjadi hal hal yang sangat menakutkan. ${ }^{33}$ Lebih tegas lagi Ellis $\mathrm{dkk},{ }^{34}$ menyatakan bahwa jika seseorang berpikir ilmiah, rasional, dan realistis akan mengalami lebih sedikit gangguan emosional. Pernyataan tersebut lebih lengkapnya sebagai berikut "Tetapi saya hanya dapat hampir menjanjikan Anda ini. Semakin Anda berpikir ilmiah, rasional, dan realistis, semakin sedikit Anda mengalami ketegangan emosional. Bukan tanpa ketegangan, karena hal itu tidak manusiawi atau supermanusiawi. Tetapi benar-benar banyak berkurang, dan ketika tahun-tahun Anda berlalu dan wawasan ilmiah Anda menjadisemakin kuat, neurosis akan semakin lama semakin sedikit dirasakan. Apakah ini sebuah jaminan? Tidak, tetapi sebuah prediksi yang kemungkinan besar akan terjadi.

\section{Penutup}

Penelitian yang dilakukan ini mengenai Peningkatan Moral Remaja Melalui Konseling Dengan Pendekatan Rasional Emotif Behavior Therapi dan Psikoedukasi. Kedua pendekatan tersebut mempunyai karakteristik berbeda dalam hal teori dan implementasinya. Hasil penelitian menunjukkan (1) terdapat peningkatan moral remaja melalui layanan konseling dengan penerapan pendekatan Rasional Emotif Behavior Therapi dan Psikoedukasi, (2) pendekatan rasional Emotif Bahavior Therapy lebih tinggi pengaruhnya terhadap peningkatan moral remaja dibanding dengan Psikoedukasi.

\footnotetext{
${ }^{31}$ Ardila, Sutoyo, dan Mulawarman, "Keefektifan Kelompok Psikoedukasi dengan Teknik Modeling untuk Meningkatkan Keterampilan Sosial Siswa."

32 "Keefektifan Kelompok Psikoedukasi Teknik Modeling untuk Meningkatkan Adaptabilitas Karir melalui Self-Efficacy Pengambilan Keputusan Karir Siswa Smp Negeri 31 Purworejo" (PhD Thesis, Universitas Negeri Semarang, 2018).

${ }^{33}$ Ellis dkk., Stress Counselling.

${ }^{34}$ Ellis dkk.
} 


\section{Penerapan Konseling Kelompok..., Purwati, M. Japar, Laili Qomariyah}

\section{Pernyataan Penulis}

Purwati Purwati dan Muhammad Japar mendesain dan melaksanakan intervensi dan pengumpulan data penelitian. Purwati Purwati, Muhammad Japar, dan Laili Qomariyah menulis draf, mereview, dan melakukan revisi naskah. Semua penulis menyepakati naskah versi terakhir ini.

\section{Ucapan Terima Kasih}

Penulis menyampaikan apresiasi dan ucapan terimakasih kepada Universitas Muhammadiyah Magelang melalui Lembaga Penelitian dan Pengabdian kepada Masyarakat yang telah memberikan pembiayaan untuk pelaksanaan penelitian ini

\section{Daftar Rujukan}

Ahmud, Muhammad, dan Mohamad Thohir. "Konseling Islam dengan Terapi Rasional Emotif Behavior untuk Mengubah Wanita Penyanyi Cafe yang Suka Minum Minuman Keras.” Jurnal Bimbingan dan Konseling Islam 3, no. 2 (2013): 184-204.

Aminah, Siti, Diana Septi Purnama, Suwarjo Suwarjo, dan Fathur Rahman. "Analisis Dampak Pelatihan Peningkatan Kompetensi Layanan Konseling Kelompok pada Guru BK SMA Se-Kabupaten Sleman.” Diklus: Jurnal Pendidikan Luar Sekolah 5, no. 2 (2021).

Ardila, Yuwinda, Anwar Sutoyo, dan Mulawarman Mulawarman. "Keefektifan Kelompok Psikoedukasi dengan Teknik Modeling untuk Meningkatkan Keterampilan Sosial Siswa." Jurnal Edukasi: Jurnal Bimbingan Konseling 5, no. 1 (2020): 34-49.

Arnett, Jeffrey Jensen. "Emerging adulthood: A Theory of Development from the Late Teens through the Twenties." American Psychologist 55, no. 5 (2000): 469-80. https://doi.org/10.1037/0003-066X.55.5.469.

Banks, Tachelle, dan Paul Zionts. "REBT used with Children and Adolescents who Have Emotional and Behavioral Disorders in Educational Settings: A Review of the Literature." Journal of Rational-Emotive \& Cognitive-Behavior Therapy 27, no. 1 (2009): 51-65.

. "Teaching a Cognitive Behavioral Strategy to Manage Emotions Rational Emotive Behavior Therapy in an Educational Setting." Intervention in School and Clinic 44, no. 5 (2009): 307-13.

Caravita, Simona C.S., Jelle J. Sijtsema, J. Ashwin Rambaran, dan Gianluca Gini. "Peer Influences on Moral Disengagement in Late Childhood and Early Adolescence." Journal of youth and adolescence 43, no. 2 (2014): 193-207. https://doi.org/10.1007/s10964-013-9953-1.

Carper, Teresa Marino, Charles Negy, Gillian Burns, dan Rachael A. Lunt. "The Effects of Psychoeducation on Thought-action fusion, Thought Suppression, and Responsibility." Journal of Behavior Therapy and Experimental Psychiatry 41, no. 3 (2010): 289-96. https://doi.org/10.1016/j.jbtep.2010.02.007. 
Caruso, Chiara, Lidia Angelone, Elisa Abbate, Valentina Ionni, Claudia Biondi, Cinzia Di Agostino, Alice Mobili, Roberta Verità, Riccardo Navarra, dan Giovanni Maria Ruggiero. "Effects of a REBT Based Training on Children and Teachers in Primary School." Journal of Rational-Emotive \& Cognitive-Behavior Therapy 36, no. 1 (2018): $1-14$.

Chan, Carmen W.H. "Psychoeducational Intervention: A Critical Review of Systematic Analyses." Clinical Effectiveness in Nursing 9, no. 3-4 (2005): 101-11. https://doi.org/10.1016/j.cein.2006.08.011.

David, Daniel. "Rational Emotive Behavior Therapy(REBT)." The Encyclopedia of Clinical Psychology, 2015, 1-8. https://doi.org/10.1002/9781118625392.wbecp077.

Dewi, Hariyati Mustika. "Konseling Islam dengan Terapi Rasional Emotif Behavior dalam Mengatasi Stres Ibu Muda di Desa Boteng Menganti Gresik.” PhD Thesis, UIN Sunan Ampel Surabaya, 2019.

Dryden, Windy. Rational Emotive Behaviour Therapy: Distinctive Features. Routledge, 2021 .

Eccles, Jacquelynne S., dan Robert W. Roeser. "Schools as Developmental Contexts." Blackwell Handbook of Adolescence, 2008, 129-48. https://doi.org/10.1002/9780470756607.ch7.

Ellis, Albert, Jack Gordon, Michael Neenan, dan Stephen Palmer. Stress Counselling: A Rational Emotive Behaviour Approach. Sage, 2001.

Flanagan, Rosemary, Korrie Allen, dan Donna J. Henry. "The Impact of Anger Management Treatment and Rational Emotive Behavior Therapy in a Public School Setting on Social Skills, Anger Management, and Depression." Journal of Rational-Emotive \& Cognitive-Behavior Therapy 28, no. 2 (2010): 87-99.

Forte, Almerinda. "Antecedents of Managers Moral Reasoning." Journal of Business Ethics 51, no. 4 (Juni 2004): 313-47. https://doi.org/10.1023/B:BUSI.0000032501.59580.33.

Hart, Daniel, dan Gustavo Carlo. "Moral Development in Adolescence the Intersection of Morality and Adolescence" 15, no. 3 (2005): 223-33.

Hastiani, dan Rustam. "Fenomena Karakter Remaja SMA Kota Pontianak dan Kajian pada Rational Emotive Behavior Therapy (Rebt) Multikultural Hastiani 1, Rustam 2" 1, no. 1 (2019): 8-20.

Kesuma, Rossi Galih, Aji Taufiq Pambudi, dan Septa Nikmatil Aliyah. "Kelompok Psikoedukasi sebagai Strategi Meningkatkan Self-Efficacy Pengambilan Keputusan Karier dan Adaptabilitas Karier Peserta Didik SMP di Kota Semarang." Dalam Prosiding Seminar Nasional: Strategi Pelayanan Bimbingan dan Konseling di Era Disrupsi, 242-47, 2018.

Killen, Melanie, dan Judith G. Smetana, ed. "Empathy-Related Responding in Children." Dalam Handbook of Moral Development, 2 ed. Psychology Press, 2013.

Krettenauer, Tobias. "Pro-Environmental Behavior and Adolescent Moral Development." Journal of Research on Adolescence 27, no. 3 (2017): 581-93. https://doi.org/10.1111/jora.12300.

Kulkarni, Subodh, dan Nagarajan Ramamoorthy. "Intra-Firm Transfer of Best Practices in Moral Reasoning: A Conceptual Framework." Business Ethics: A European Review 23, no. 1 (Januari 2014): 15-33. https://doi.org/10.1111/beer.12035. 
Lukens, Ellen P., dan William R. McFarlane. "Psychoeducation as Evidence-Based Practice: Considerations for Practice, Research, and Policy." Brief Treatment and Crisis Intervention 4, no. 3 (2004): 205-25. https://doi.org/10.1093/brief-treatment/mhh019.

Mayhew, Matthew J., dan Patricia King. "How Curricular Content and Pedagogical Strategies Affect Moral Reasoning Development in College Students." Journal of Moral Education 37, no. 1 (1 Maret 2008): 17-40. https://doi.org/10.1080/03057240701803668.

Mechanic, David. "Improving the Quality of Health Care in the United States of America: The Need for a Multi-level Approach." Journal of Health Services Research and Policy 7, no. SUPPL. 1 (2002): 35-39. https://doi.org/10.1258/135581902320176359.

Mello, Zena R, dan Frank C Worrel. "The Past, the Present, and the Future: A Conceptual Model of Time Perspective in Adolescence." Time Perspective Theory; Review, Research and Application: Essays in Honor of Philip G. Zimbardo, 2015, 1-551. https://doi.org/10.1007/978-3-319-07368-2.

Mouratidou, Katerina, Stavroula Goutza, dan Dimitrios Chatzopoulos. "Physical Education and Moral Development: An Intervention Programme to Promote Moral Reasoning through Physical Education in High School Students." European Physical Education Review 13, no. 1 (1 Februari 2007): 41-56. https://doi.org/10.1177/1356336X07072675.

Neimeyer, Robert A. "Grief Therapy as Intervening in Meaning: Principles and Practices." Dalam Alleviating World Suffering, 165-79. Springer, 2017.

Nugroho, Imam Setyo. "Keefektifan Kelompok Psikoedukasi Teknik Modeling Berbasis Nilai-Nilai Islam untuk Menurunkan Moral Disengagement dan Meningkatkan Integritas Akademik Siswa." PhD Thesis, Universitas Negeri Semarang, 2019.

Pambudi, Aji Taufiq. "Keefektifan Kelompok Psikoedukasi Teknik Modeling untuk Meningkatkan Adaptabilitas Karir melalui Self-Efficacy Pengambilan Keputusan Karir Siswa SMP Negeri 31 Purworejo.” PhD Thesis, Universitas Negeri Semarang, 2018.

Pandey, Ashish, Rajesh Chandwani, dan Ajinkya Navare. "How Can Mindfulness Enhance Moral Reasoning? An Examination Using Business School Students." Business Ethics: A European Review 27, no. 1 (Januari 2018): 56-71. https://doi.org/10.1111/beer.12171.

Paturrochmah, Hany. "Rasional Emotif Behavior Therapy (REBT) Islam dalam Menumbuhkan Sikap Mental Positif." Konseling Edukasi: Journal of Guidance and Counseling 4, no. 2 (2020): 200-217.

Schmidt, Christopher D., Charles R. McAdams, dan Victoria Foster. "Promoting the Moral Reasoning of Undergraduate Business Students through a Deliberate Psychological Education-based Classroom Intervention." Journal of Moral Education 38, no. 3 (1 September 2009): 315-34. https://doi.org/10.1080/03057240903101556.

Terjesen, Mark D., dan Robyn Kurasaki. "Rational Emotive Behavior Therapy: Applications for Working with Parents and Teachers." Estudos de Psicologia (Campinas) 26 (2009): 3-14.

Trevino, Linda K., dan Stuart A. Youngblood. "Bad Apples in Bad Barrels: A Causal Analysis of Ethical Decision-Making Behavior." Journal of Applied Psychology 75, no. 4 (1990): 378-85. https://doi.org/10.1037/0021-9010.75.4.378. 
Vitell, Scott J., Robert Allen King, Katharine Howie, Jean-François Toti, Lumina Albert, Encarnación Ramos Hidalgo, dan Omneya Yacout. "Spirituality, Moral Identity, and Consumer Ethics: A Multi-Cultural Study." Journal of Business Ethics 139, no. 1 (November 2016): 147-60. https://doi.org/10.1007/s10551-015-2626-0.

Warzuknidini, Warzuknidini, Amelia Pramono, dan Marindra Firmansyah. "Pengaruh Psikoedukasi Pencegahan Penyalahgunaan Narkoba terhadap Perubahan Sikap Mahasiswa Fakultas Kedokteran Universitas Islam Malang." Jurnal Bio Komplementer Medicine 7, no. 1 (2020).

Worthington, Everett L., dan Diane Langberg. "Religious Considerations and Selfforgiveness in Treating Complex Trauma and Moral Injury in Present and Former Soldiers." Journal of Psychology and Theology 40, no. 4 (2012): 274-88. https://doi.org/10.1177/009164711204000403.

Zimbardo, Philip G., Kelli A. Keough, dan John N. Boyd. "Present Time Perspective as a Predictor of Risky Driving." Personality and Individual Differences 23, no. 6 (1997): 1007-23. https://doi.org/10.1016/S0191-8869(97)00113-X. 